\title{
What does Europe Want?
}

\author{
Raluca Bejan, University of Toronto
}

Srećko Horvat and Slavoj Žižek, Ce vrea Europa? Uniunea şi Necazurile cu Ea [What does Europe want? The European Union and its Troubles] (New York: Columbia University Press, 2015)

The essays contained in this book alternate between Srećko Horvat and Slavoj Žižek. The book opens with a foreword by Alex Tsipras, Greece's current Prime Minister and leader of the Syriza party, and concludes with his interview as moderated by the two writers. The authors' ideas flow and build upon each other; hence this review does not take a chapter-by-chapter approach. It rather discusses the topics thematically, on an argument-by-argument basis, without a clear demarcation of who said what.

\section{On Syriza}

Alex Tsipras focuses on the topic of (economic) neoliberalism, which, he argues, flourished within the last two decades as the most aggressive form of capitalism. After the 2008 recessionary context that affected the Greek economy (limited to consuming goods imported from the wealthier European countries), faux pas ideas of economic stability (i.e. indirect taxation of the public sphere, the devolution of the welfare state and the privatization of fundamental services such as education or health) and market reform (i.e. the elimination of collective bargaining) transferred the negative effects of economic speculation onto national governments, and, in turn (under the guise of austerity programs) on the backs of ordinary people. Tsipras uses the analogy that one cannot take a quarter of a cow's grass and expect her to produce four times more milk.

He further outlines two strategies to accurately deal with the Greek crisis: first, via increased state control over the economy (i.e. printing a new currency, nationalizing the banks and taxing the rich); and second, via the transferal of financial debts onto the public sector and taxing the middle and lower classes. The two are conflicted. One defends the capital and the other defends the European social contract and people's social needs. Tsipras states that the only viable alternative is to emancipate the economy from the constraints of the profit, by adopting a new model of production, based on adequate labour conditions, public good and environmental protection. He also argues that the welfare state is neither a gift nor a waste of money: it is financed via employment contributions. Hence, it is a progressive form of wealth redistribution. He makes reference to 
Chavez's Venezuela as an example of a state that combines economic growth with the reduction of social inequalities. It is a model for Syriza and for the entire left in the world, Tsipras concludes, in terms of creating a people based economy rather than a profit centered one.

Throughout the book, both authors refer to Syriza as a possible catalyst for the Derridian l'avenir (as the unpredictable messianic path) and compare Tsipras's party with a sign of a new direction, a voice of rationality against the free market ideology. Horvat and Žižek argue that the unknown potentiality in Syriza is what exacerbates the panic in the European establishment; for instance, the German newspaper, Der Spiegel, placed Tsipras on a list of top-ten most dangerous politicians, alongside right-wing extremists, such as the French Marine Le Pen from the National Front, the Finnish nationalist Timo Soini, the Austrian Hans-Christian Strache and Holland's extreme populist, Geert Wilders.

\section{On a Free Market Troll}

Discussions oftentimes read like a squash game between the two authors. Žižek critiques our naïve defensiveness of "pure" capitalism and our societal thinking around free market fundamentalism (i.e. even if things are bad, they do not cancel the idea in itself; rather, we infer that we did not apply it properly). It is why the 2008 crisis was seen to result from excessive welfare state regulation and not from free-market fundamentalism. Horvat continues by problematizing our collective psychology around investing. The winner is not the one who invests the most but the one who best understands the psychology of the masses. Similarly, the price of a stock is determined by opinions about the value of the stock and not by its base value proper.

Žižek goes one step further, by reasoning that the competitive market logic gets extended to all social domains. The individual is re-conceptualized as self-entrepreneurial, and the individualization of social politics is aligned to market norms. Salaries and pensions no longer increase, yet people have access to consumer credits as substitutes. There is no guaranteed right to housing or to higher education, yet mortgages or school loans are easily available. Workers become indebted workers, consumers -indebted consumers, and citizens - indebted citizens. It is within such context that the indebted subject performs two types of work: the salaried work and the work upon the self, to produce a debt-paying subject that intrinsically assumes guilt for being an indebted subject. Indebtedness is temporally regulated: the ability to repay one's debt (in the future) is conditioned on a predicted, regulated and calculated behavior (in the present), hence any default triggers an assumed individual fault. The entrepreneurial self becomes more regulated than if it was to be subjected to any form of authoritative discipline. The final victory of capitalism lies exactly in the commodification of work: the individual is the ultimate self-entrepreneur, willingly investing (via indebtedness) in his own future (via education, health, etc.). Both the worker and the capi- 
talist are now investors, and this logic closes the transaction between labour and capital.

Debt, as an instrument of behavioural change, gets similarly applied to larger institutions and countries: for instance, it is the good payback behaviour, in market terms, that is continually evaluated by credit rating agencies. Such logic rests on the false idea that debt needs to be repaid, Žižek argues. Yet the United Sates (US) proved, in the last 40 years, that you can live well without paying your debts. The paradox is that debts are irrelevant, almost nonexistent, since humanity can only produce what it consumes (i.e. debt par excellence only matters vis-à-vis natural resources, as in owing to the next generations the survival of material conditions). But now, global debt surfaces when a nation consumes more than it produces (i.e. the US), therefore a different group/nation needs to consume less.

It is debt that keeps the indebted in permanent dependency and subordination. A pardon(ing) or mercy gesture does not cancel the debt per se but it makes it infinite - we are forever grateful to the one that forgave us. Yet compassion is always correlated with sovereignty_only the sovereign can dispose of pity. By investing in the public good, art, sciences and health, the capitalist denies his own personification (i.e. earning money just to earn more money) and becomes an ethical subject (i.e. George Soros or Bill Gates); however, it is through the sovereign gesture of giving that the capitalist breaks the vicious circle of unlimited reproduction.

\section{Crisis, Crisis, Crisis}

Žižek analyzes the Cypriot and Greek political situations through a double entendre scenario: Cyprus could not maintain its prosperity within Europe nor without Europe. Both rhetorical stories - the German version of Cypriot money laundering and the Cypriot version of the European Union (EU) measures as a new manifestation of German occupation-were in fact masking that Cyprus was a symptom of a failed system: that of uncontrollable financial situations bankrupting entire countries. Similarly, in Greece, there was the German-European story of the lazy and irresponsible Greeks not paying their taxes, hence needing to be financially disciplined, and the Greek version of national sovereignty attacked by Brussels' technocratic neoliberalism.

Yet none of these are satisfactory, Žižek argues. For instance, to solve the Cypriot banking crisis, a radical change of the whole banking system would have been needed. For the Greeks, who became a guinea pig for neoliberal austerity politics, at war with the European economic establishment, their biggest need would have been for solidarity. The paradox is that Europe pressured Greece to pay its debt while ruining its economy via austerity (i.e. the post-austerity economic damages were reported as calculation errors by the International Monetary Fund (IMF) and were three times higher than initially anticipated).

The EU pressure on Greece matches the "superego" in psychoanalysis, 
Žižek argues. The superego is the one bombarding the subject with impossible requests, subsequently content about her inability to respect them. The more we listen to its solicitations, the more guilty we feel, hence the Greek failure is just part of the game.

\section{Austerity and Nationalism}

Austerity produces a fertile ground not only for the flourishing of capitalism, but also for the ascension of extreme right politics and new forms of nationalism. Although austerity and privatization constitute the real causes for unemployment, societal discontent is oftentimes mobilized in nationalist and fascist public discourses. The terms "workers" and "workers' rights" are also used by the political right (i.e. in Czech Republic the extreme right party is called The Party of the Worker) to position workers against each other: German workers versus Greek workers; Austrian and Greeks versus immigrants. This also explains why Greece's fascist party, Golden Dawn, is an arm's length extension of the system. This type of political polarization is common across Europe, Žižek argues, from East to West, from Poland to Norway, Sweden and Hungary. Now we have a center party (i.e. Christian democrat, liberal conservative and popular) sustaining global capitalism and cultural liberalism (i.e. tolerance for abortions, gay rights, ethnic and religious minorities) and an opposing anti-immigration populist sliver constituted by neo-fascist and racist fractions: Germany's National Democrats, France's National Front and Jobbik in Hungary.

\section{Austerity and Immigration}

Both authors rationalize the hatred against immigrants as a by-product of austerity. Horvat references the famous Mannoni line, "Je sais bien mais quand-même" [I know damn well but...] to explore the structure of fetishist denial vis-à-vis Croatian racism: "I am not racist but black people are walking our streets, stare at our children and steal our fruits." Such thinking is also manifested in policy making: from 1997 to mid-2011, the Croatian government received approximately 2000 requests for political asylum yet only granted entry for 42 claims. If there is no contact with the other, Horvat states, the possibility of understanding and learning is reduced. Ironically, Croatians are seen in the EU in the same way that African immigrants are seen in Croatia.

Italy constitutes another example. In 2009, Berlusconi launched a municipal campaign against non-Italian foods, which were banned via bylaws in Luca and Milan. These bylaws discriminatorily affected migrants selling ethnic foods. The former Bossi-Fini law, introduced in 2002, also restricted entry visas to migrants' work contracts. Italy has only 8000 migrants, a fairly low number in comparison with the $40000-50000$ in France and Germany. Yet the Berlusconi administration instilled a public anti-immigrant fear (i.e. anti-ethnic food, night raids). In 2009, a boat with 80 migrants sank after floating allegedly unobserved 
between Lampedusa and Libya for almost twenty days. The Italian border police only saved five of the African immigrants found on the boat. Earlier, in 2007, seven Tunisian fishermen were threatened with fifteen years in prison for saving 44 African migrants who would have drowned otherwise. Letting migrants die would break the international maritime laws but saving them would trigger correctional problems with municipal bylaws. Ironically, Horvat states, those letting people die are left unpunished while those trying to save them are convicted.

\section{The Balkans and the Post-Soviet Bloc vis-à-vis EU Integration}

EU integration was always positioned to escape the Balkans. For instance, in the Croatian referendum, the choice was presented between joining the EU and becoming part of the West, and remaining stuck in the backwardness of the Balkans. When Croatia started its integration efforts in 2005, a Croatian newspaper published an article titled "Bye Bye Balkans." A similar rhetoric was at play in Slovenia, that joining EU would bring the country closer to the European ideal. The taken-for-granted attitude that the Balkans are in need of civilizing via integration into the EU and the West plays on the old idea of the region as the Other of the Occident - the reprised face of the European self, the place of ethnic conflicts surpassing civilized Europe.

Horvat identifies three myths commonly shared by Balkan candidate countries for EU integration. First, the myth of unsolvable corruption. Romania joined the EU in 2007 yet it could not join the Schengen Zone (the EU travel area free of border controls) due to corruption claims. Ironically, such monitoring rules are never applied (by the new member states for example) to Europe itself. The second myth relates to the ideal of increased prosperity post-integration, despite contradictory evidence. For instance, youth unemployment reached $40 \%$ after Croatia joined the EU, lagging behind Greece and Spain. The third myth is that the Balkans are a dark, war-crimes region, which also sustains the idea that an integrated Croatia, for example, would open a conciliatory process with Montenegro and Serbia. It is assumed that the EU, with its "mission civilisatrice," will rescue the Balkans, although in reality, the EU never stopped the development of any actual problems in the region (i.e. the Srebrenica massacre).

Horvat also mentions Angelina Jolie's film In the Land of Blood and Honey, as presenting another cliché story of ethnic hatred and nationalism between Serbs and Muslims in the area. While Jolie's film constituted an important step in raising awareness about the 50000 Bosnian women raped by Serb soldiers, it did not say a word about the big war magnates using the war as a pretext to rob (i.e. to privatize) state-owned companies and industries. In transporting Max Horkheimer's discourse that "who does not want to talk about neoliberalism should also shut up about EU" (38), Horvat argues that those who do not want to talk about financial reforms should also keep quiet about human rights or judicial reforms.

After the fall of communism, the transition to a free market economy 
was the only economical way made viable in the East. This played on societal assumptions that democracy is synonymous with western consumerism, Žižek states. Therefore, post 1989, a wave of massive privatization took place in the Eastern Bloc (examples include the health care system in Romania and the criminal justice and energy sectors in Croatia).

Horvat and Žižek both discuss some of the Eastern political ambiguities. For instance, the paradox of pro-Americanism anti-Americanism. Post-communist countries are the biggest supporters of the American war against terror, yet they wish for their cultural identity to survive as non-Americanized. The cultural narcissism of Eastern Europe, self-assessed as un-corrupted by cultural Americanism, is grounded in the same Western clichés that catalogued post-communist countries as the West's uncivilized, poor, and backwards relatives. Such equivocality mirrors the ambivalent Western rhetorical inconsistencies towards the East.

\section{Some Ending Thoughts}

For those regularly engaging with Žižek's thoughts, the book might come across as repetitive. Horvat, as well, falls into a pattern of Žižekian analogies. One might feel like one is reading the same person throughout. Horvat's analysis on the Balkans seems nuanced, detailed and factually oriented. He also focuses on migration issues, yet in a superficial manner, somewhat resembling a newspaper tabloid style.

Perhaps what needs to be contested is Žižek's insistence on the idea and ideal of Europeaness. Statements such as "Europe is going downhill and the 3rd world cannot generate a strong counter position to the American dream," that "despite everything that Europe could be blamed for it is still Europe who gave people the idea of radical egalitarism and radical democracy," hide underneath the centrality of Eurocentrism as a concept, and go against Žižek's own re-application of Horkheimer's thought, "that if you keep quiet about Europe you should also keep quiet about the United States" (46). If we criticize Americancentrism there is also a need to criticize Eurocentrism. The two are not mutually exclusive and should not be sustained on behalf of abstract ideals of radical egalitarism.

Next, it is difficult to conceptualize the anti-immigrant feeling solely as a by-product of austerity, since there are no longitudinal studies to generally show a causal relation between austerity and anti-immigrant sentiment, nor to measure cross-country societal attitudes pre- and post-austerity. We can refer for instance to the recent Brexit vote to leave the EU, which was mainly balloted against Eastern Bloc migration and Muslim refugees. It is solely an assumption to state that the anti-immigrant feeling that prevailed in the Brexit campaign was caused by the 2008 recession and subsequent austerity cuts. In fact, xenophobia was also present in $\mathrm{UK}$ at the height of the welfare state: examples including the race riots 
of 1958 or the 1970 racist attacks against the Pakistani community.

Lastly, the book is less relevant now for the Syriza movement, as many changes within this left political faction occurred within the last year, particularly during the summer of 2015, after Greece defaulted on the Troika-imposed memorandum terms and after the OXI vote, which rejected the memorandum package ultimately endorsed by Syriza. ${ }^{1}$ This subsequently fractioned the alliance-40 MPs formed a new radical left fraction, Popular Unity. ${ }^{2}$

Despite some of the noted limitations, the book provides a strong, emancipatory contribution to some of the contemporary political issues that we are confronted with globally. 


\section{NOTES}

${ }^{1}$ Troika refers to the tripartite decision group composed by the European Commission (EC), European Central Bank (ECB), and the IMF.

${ }^{2}$ Bejan, Raluca. "'Democracy Rising: From Insurrections to 'Event"'-Athens 2015: A conference report and a conversation with Giovanbattista Tusa and Creston Davis of the Global Center for Advanced Studies." Transnational Social Review. A Social Work Journal (2016): ahead of print. 